\title{
Kurt Grelling and the Idiosyncrasy of the Berlin Logical Empiricism
}

\author{
Nikolay Milkov \\ Department of Philosophy \\ University of Paderborn \\ nmilkov@mail.uni-paderborn.de
}

\begin{abstract}
"How outlandish he [Grelling] approaches everything, how traditional. Fries, Nelson,
Oppenheim, etc. One can't assimilate it easily, a lot of thereof remains undigested".

Otto Neurath's letter to Rudolf Carnap, March 16, 1935. (RC 029-09-70)
\end{abstract}

\begin{abstract}
The received view has it that Hans Reichenbach and his friends of the Berlin Group worked close together with the more prominent Vienna Circle. In the wake of this view, Reichenbach was often treated as a logical positivist - despite the fact that he decisively opposed it. In this chapter we follow another thread. We shall show the "third man"- besides Reichenbach and Walter Dubislav - of the Berlin Group, Kurt Grelling, as a man who could grasp the academic trends of the time faster than anybody else, who was better informed about logic and philosophy of nature than his two prominent colleagues and thus, could better delineate, although tentatively, central threads of research of the Berlin Group. Grelling did this on several occasions, but most ostensibly in the last years of his life when he was focused on problems of formal ontology. On the basis of this analysis, we shall see that in the early 1920s, Reichenbach too was led by a project in ontology of science that he elaborated together with the psychologist Kurt Lewin. Moreover, Reichenbach's later philosophy of nature was also shaped by this project. We present this direction of philosophy of science as a "road less travelled" which, however, if revived, can point to a new direction that will more closely connect philosophy and science.
\end{abstract}

Keywords: Grelling, formal ontology, Hempel, Reichenbach, scientific metaphysic

\section{XY. 1. Introduction}

In the last decades, philosophy of science often concentrated its attention on intricate epistemological problems: scientific explanations as different from scientific descriptions, scientific truth, the relation between phenomena and data of science, the relation between scientific theories and scientific models, etc. Arguably, the result is "the decline of the philosophy of science in the academy and in the public intellectual sphere" (Howard 2003, 77). Here is a recent statement of the physicist and cosmologist of repute Lawrence Kraus: "The only people, as far as I can tell, that read work by philosophers of science are other philosophers of science. It has no impact on physics whatsoever and I doubt that other 
philosophers read it because it's fairly technical" (quoted in Andersen 2012). ${ }^{1}$ We remember quite well, however, that at the beginning of the last century, the philosophical writings of David Hume, Ernst Mach, and Henri Poincaré helped Einstein to formulate his special theory of relativity. In historical context, this development was described by Don Howard in the following words:

\begin{abstract}
In the 1950s and 1960s the philosophy of science was one of the most exciting places to be in the academy. Not just in the philosophy departments but from many other places on the typical North American campus, the philosophy of science was seen as one of the most important centers of intellectual activity. [...] The times, however, have changed. I have the impression that today, on more and more campuses, the philosophy of science is moving toward the periphery. (Howard
\end{abstract} $2003,74 \mathrm{f}$.

The question raises itself: Why this change for the worse?

As we see it, this state of art is a long-term outcome of the logical positivists highly influential approach to philosophy of science. In a Chapter titled "Against Philosophy” of his book Consilience, the Nobel Prize winner for physics for 1979 Steven Weinberg wrote: "The positivist concentration on observables like particle positions and momenta has stood in the way of a 'realist' interpretation of quantum mechanics, in which the wave function is the representation of physical reality" (Weinberg 1992, 181). ${ }^{2}$

Unfortunately, the post-positivist philosophers of science didn't fare better. Above all, Quine's programmatic claim that philosophy is a part of natural science didn't help to really put science closer to philosophy. The same can be said about the philosophy of science as autonomous discipline that was established and also institutionalized in North America in the 1960s, and then in the whole world. Furthermore, there are good reasons to maintain that the road to it was paved by the appearance of Hempel's and Oppenheim's "Studies in the Logic of Explanation" (1948). Today, after seven decades of research, the exploration of the explanation in science continues full steam ahead. Unfortunately, science itself learned less about its philosophy from this discussion. The new movement of 'scientific metaphysics' that came to the scene in the 1970s, inspired by works of Saul Kripke and Hilary Putnam, proved even less helpful. In short, the conclusion can be drawn that "no new paradigm has come to the fore to define the field following the demise of neo-positivism" (Howard 2003, 76).

\footnotetext{
${ }^{1}$ A similar position is described and defended in Clark Glymour's chapter in this volume.

${ }^{2}$ About this interpretation of quantum mechanics and what role positivism played in the story, see Michael Stöltzner's chapter in this volume.
} 
In this Chapter, we shall try to track down an alternative venue that, we hope, can help to bring philosophy and science back together. To this purpose, we are going to rationally reconstruct the project of the Berlin Group, led by Hans Reichenbach. We are going to do this by a close analysis of the works of "the third man" of the group (Peckhaus 2013), Kurt Grelling (1886-1942). We shall see that he made several instructive gestures towards promising sides of the project of the Berlin Group.

By this endeavor, we follow a specific historical-philosophical approach. In short, we are not going to only logically analyze the philosophical ideas of Kurt Grelling and their relatedness to other philosophers of the time, including other members of the Berlin Group. We shall also explore the historical context of these ideas, including their psychological side. Following this approach, we hope to reveal aspects of the philosophical development of the Berlin Group that otherwise remain unnoticed.

\section{XY.2. Kurt Grelling}

\section{XY.2.1. Kurt Grelling between Leonard Nelson and Hans Reichenbach}

Hans Reichenbach insisted that we are to investigate science not only from a logical point of view but also sociologically and psychologically (Milkov 2015, p. xl). Clearly, we can explore this way also the philosophical development of the members of the Berlin Group. In the case of Kurt Grelling, a psychological analysis is especially appropriate. In the sequel we are going to see why was this so.

Kurt Grelling started his study in 1906 in Göttingen with Leonard Nelson, a NeoFriesian philosopher who in 1919 received, with the decisive support of David Hilbert, an "associate professorship [außerordentliche Professur] for systematic philosophy of exact sciences". In 1908 Grelling discovered the famous today "Grelling paradox", in 1910 he wrote a Dissertation under, perhaps, the best pure mathematicians of the time, David Hilbert and Ernst Zermelo, on the Göttingen-typical topic of axiomatisation of arithmetic (Grelling 1910a). ${ }^{3}$ Also in 1910, at the age of 24, Grelling published an important paper on theory of probability (Grelling 1910b). In the same year, on August 3, 1910, he wrote a letter to Bertrand Russell in which he communicated problems that he supposedly discovered in Russell's ramified theory of types (Bertrand Russell Archive, McMaster University).

\footnotetext{
${ }^{3}$ After the discovery of the paradox of classes by Russell, David Hilbert and his group concentrated efforts in avoiding paradoxes by axiomatisation of mathematical disciplines and making the definitions of their terms more precise.
} 
Instead of fighting for a university position in logic, however, Grelling started studying political economy in the University of Munich for three years (1910-13). Apparently enhancing his knowledge in this realm was more important to him than the dogged pursuit of academic career. Among other things, in 1912/13 Grelling organized an informal philosophical seminar in Munich in which also Reichenbach could have taken part in that year, Reichenbach was also studying in Munich. Be this as it may, it is well documented that while in Munich, Grelling and Reichenbach came in contact as members of the left-oriented "Free Students" Society.

After he returned in Göttingen, Grelling found Nelson occupied mainly with political issues - a development caused by the upcoming Great War and the social changes of the time. Indeed, Grelling continued to work on philosophy of mathematics. In January 20, 1914, for example, he lectured in Hilbert's Mathematical Colloquium in Göttingen on "Recent Works in Philosophy and Mathematics", and on December 18, the same year, delivered “Additions and Exact Formulations" to Heinrich Behmann's lecture on Russell's and Whitehead's Principia mathematica (Corry 2004, 319 n. 11). But he also engaged with political philosophy, producing, among other things, paper on the "Philosophical Foundations of Politics" (1916a) and the brilliant pamphlet Anti-j'accuse (1916b) ${ }^{4}$ in which he tried to explain the causes and reasons for the Great War.

Grelling's academic priority, to achieve ever more knowledge instead of fighting for academic posts, made him most informed in the field of scientific philosophy, in fact, better informed than either Nelson or Reichenbach. For example, while Reichenbach had practically no idea of the role of Frege as a logician, ${ }^{5}$ Grelling knew much about Frege's logic already when he worked together with Nelson. This knowledge was demonstrated, for example, in Grelling's (1932/33) critical discussion of Dubislav's book The Definition in which he, among other things, sharply criticized Dubislav's interpretation of Frege. Grelling also wrote papers on Russell, Gödel, Carnap, Tarski and Leśniewski. Based on that knowledge, in the late 1920s and in the 1930s, Grelling successfully played the role of a very well-informed analytic "gadfly" (to use here this happy expression of Richard Rorty) who criticized the

\footnotetext{
${ }^{4}$ The book was immediately translated into Swedish and published in Stockholm in the same year and into French in the next year in Zürich.

${ }^{5}$ This is clear, for example, from Reichenbach's short review of the history of logic in which he states that "we may date the modern period of logic" from George Boole who started the first phase of the modern logic. Russell's The Principles of Mathematics (1903) signals “the second phase of modern logic" (Reichenbach 1944, 24 f.) No word about Frege.
} 
latest developments of logic, science, philosophy of science and the philosophy of nature of his time.

Grelling was also an avid translator of scientifically informed philosophers of the time. Already in 1910 he translated a book of Federigo Enriques from Italian. Between 1927 and 1930 Grelling translated four books by Bertrand Russell from English, and in $1930 \mathrm{a}$ book by Émile Meyerson from French. We can judge the quality of Grelling's translations from the words of Meyerson in the "Preface" of the German translation of his Identität und Wirklichkeit (this is the case since Émile Meyerson studied in Germany and was fluent in German, so he could read Grelling's translation in original): "Dr. Grelling fulfilled the obligations of the translator a in seldomly achieved perfect way. I can confirm that I read some pages [of the translation] with a real pleasure" (Meyerson 1930, xi).

Eventually, this side of Grelling's academic character made him "the third man" of the Berlin Group behind Reichenbach and Dubislav (Peckhaus 2013). Typically, Grelling never delivered a lecture at the Society of Empirical/Scientific Philosophy which, after June 1929, was run by the Berlin Group of which Grelling himself was a core member. Being at the time only a high-school teacher in Berlin, he consigned this task to Reichenbach and Dubislav. A few years later, however, apparently hoping that this will help him to finally find an academic or research position away from Nazi Germany, he delivered talks at the International Congresses for the Unity of Science in Prague (1934), and Paris (1936, and 1937).

Grelling's career is sometime seen as movement from being a collaborator of Nelson's to being a collaborator of Reichenbach's (Peckhaus 1994). This, however, is anything but the whole truth about him as a scientifically informed philosopher. Exactly because of the peculiarities of his academic character, he incorporated the spirit of the Berlin Group like nobody else. His encyclopedic knowledge in logic, mathematics, and politics made him 'the great unknown' of the Berlin Group, the hidden figure behind its façade. In film industry there is an idiosyncratic concept of 'best supporting role'. The artist assisting the main actor gives her the opportunity to unfold her talent. Kurt Grelling played similar role to the developing philosophy of logical empiricism in Berlin.

\section{XY.2.2. Fries and Nelson}

In order to become better acquainted with Grelling's academic position, we shall first go back to his training in the context of the Jacob Fries Society led by Leonard Nelson (cf. Milkov 
2013, 12). Against the conventional view, which heavily underlines the role of Ernst Cassirer, we see that the logical empiricism as practiced by the Berlin Group as deeply rooted in that Society.

Traditionally, Jacob Friedrich Fries (1773-1843) is characterized as a Kantian who tried to reorient Kant towards psychology. Fries, however, was anything but a psychologist in the sense of Frege or Husserl. He simply defended the famous regressive method, formulated already by Kant (1800, $\S 105)$, according to which philosophy is to start its analysis from the complex and confused data. In contrast to Kant, however, Fried didn't start from the data of experience but from the data of sciences, and this in order to go back (to "regress") to their grounds - i.e. to discover their principles (sie herauszuschälen).

At the beginning of the $20^{\text {th }}$ century, Fries' philosophy of science was rediscovered by Leonard Nelson. Nelson (1905) fought the "obscurantism" of the Neo-Kantians that is not really scientific (cf. Grelling 1907). Similarly, Fries, whose ideas were positively attested by scientists of the time like Carl Friedrich Gauß and Alexander von Humboldt, criticized Kant in that the latter only pays a lip service to science. To be more exact, he discusses a small area of mathematics and science. "For example, Kant never seriously undertook the philosophical analysis or justification of calculus, of formal algebra, of the theory of probability, or of analytical mechanics" (Pulte 2013, 45). Beyond Kant's interest also remained chemistry, which he considered reducible to physics. One of Fries' objectives was to extend Kant's philosophy to all sciences.

We know today, thanks to Michael Friedman (2001), that in 1920 Hans Reichenbach adopted the conception of relative a priori (Reichenbach 1920/1965). To be more specific, he replaced Kant's a priori, which is valid for all kinds of science once and forever, by "relativized, and dynamic, constitutive principles, which change incoherently from one theory to another" (Friedman 2005, 125). The key point was the rejection of the Kantian thesis that knowledge as such, and scientific knowledge in particular, has eternal general principles. "There are no general presuppositions of knowledge, only presuppositions of particular hypothesis" - or of current theory (Reichenbach 1931/1978, 362); and exactly these individual presuppositions have to be brought out by the logical analysts of science.

Recent studies show, however, that already Jacob Fries adopted a kind of relative a priori. Prima facie, Fries followed Kant's synthetic a priori. But he also specified that, according to him, every specific scientific theory, "the theory of electricity or magnetism, for example, may have its own maxim that can gain constitutive relevance" (Pulte 2013, 46). 
Furthermore, these maxims are relative - they can be revised by new scientific discoveries and theories.

\section{XY.2.3. Grelling and Reichenbach}

We have already noted (in XY.2.1) that it is possible that Reichenbach visited Grelling's philosophical seminar in Munich (1912/13). However, there are independent good reasons to believe that Kurt Grelling animated Reichenbach to deal with probability. Recall that as far back as in 1910, Grelling published the paper "The Philosophical Foundations of the Probability Calculus" (1910b), in which he defended the objective interpretation of this discipline against Carl Stumpf's subjectivism. Besides, Grelling linked his thoughts on probability to the problem of induction. These two approaches were the kernel of Reichenbach's theory of probability during his whole career.

In his dissertation (1915), Reichenbach discussed Grelling paper on induction as well as Jakob Friedrich Fries' Essay on the Critique of the Principles of the Probability Calculus (1842) and Ernst Friedrich Apelt's (one of Fries' students) Theory of Induction (1854). This cannot be surprising since, during Reichenbach's work on his dissertation in 1914, Grelling was on hand with help and advice, a fact confirmed in an autobiographical note of Reichenbach dated in 1927: "Probability has to be introduced as a foundation-this objection was already made to me by Grelling in 1914." (HR 044-06-21)

Although Grelling's and Reichenbach's paths did not cross between 1914 and 1926, they kept in touch. Moreover, as we learn from Grelling's postcard to Reichenbach from October 10, 1921, he answered positively to Reichenbach's request to use Grelling's “formulation" (HR 015-54-06). We don't know which exactly formulation Reichenbach meant here. More clear is that the formulation in question comes from Grelling's paper "Theory of Relativity and Critical Philosophy" that he delivered at the Jacob Fries Society on August 15, 1921, of which Grelling apparently sent a copy to Reichenbach.

Grelling's paper was substantially based on Reichenbach (1920/1965) and was, in fact, the most positive reaction to Reichenbach's book in the time, showing Grelling once again as a man who closely followed the new events in scientifically informed philosophy. His conclusion was that "the theory of relativity seriously undermines the conception of a priori of the critical philosophy". 6 This position meant an actual break with Leonard Nelson and his Group who clearly failed to adopt "the conventionalist and fallibilist elements of

\footnotetext{
${ }^{6}$ Nachlass Nelson, 90 Ne 1, Nr. 388, pp. 243-46; here p. 243.
} 
Fries' philosophy of science [as well as] his theory of space." (Pulte 2013, 51) His

philosophy of science remained "radically conservative" (original emphasis). It continued to pursue a "certistic" conception of scientific knowledge.

Reichenbach's high regards for Grelling in these years was confirmed in the beginning of February 1923 when Reichenbach started, together with Carnap, to prepare the famous Erlangen-workshop on exact philosophy that took place in March the same year. Reichenbach first sent invitation letters to four persons only: Schlick, Paul Hertz, Kurt Lewin and Kurt Grelling. ${ }^{7}$ Grelling's answer to Reichenbach is not preserved but apparently he declined the invitation. ${ }^{8}$ Our guess is that the negative answer came because exactly in the first months of 1923 Grelling had to move from Göttingen to Berlin.

Grelling and Reichenbach resumed their regular meetings only when Reichenbach moved from Stuttgart to Berlin in October 1926. In fact, these were the first steps in setting up the real Berlin Group. This suggestion is supported by the "Preface" of Reichenbach's The Philosophy of Space and Time, which informed the reader that Grelling read the book in manuscript and made "friendly criticism concerning some details" (1928, iii).

\section{XY.2.4. Grelling's Ontological Turn}

After 1936, and until 1939, when he was interned in South-France, Grelling concentrated his efforts on formal ontology. In this short period he developed as a systematic scholar who partly abandoned his old preoccupation of philosophical interpreter. In these few years he wrote six papers on formal ontology:

(i) “The Concept of Gestalt in the light of Modern Logic", with Paul Oppenheim (1937/38/1988);

(ii) "Logical Analysis of 'Gestalt' as 'Functional Whole”, with Paul Oppenheim (1939/1988);

(iii) “A Logical Theory of Dependence" (1939/1988);

(iv) "Melody as Gestalt";

(v) “On Definitions by Equivalence and By Group Invariants" (1969);

(vi) “On the Logical Relations between Groups and Equivalence” (1970).

\footnotetext{
${ }^{7}$ Cf. Reichenbach's letter to Schlick of 03.02.1923. (Schlick's Archive)

${ }^{8}$ This is clear from the prospective program of the Workshop Carnap prepared two weeks later, on 19.02.1923, in which Grelling's name is not included. (HR-015-50-03)
} 
Grelling started (together with Paul Oppenheim) his ontological investigation from Christian von Ehrenfels' programmatic paper “On Gestalt Qualities” (1890). A typical example of a Gestalt discussed by Ehrenfels is melody: it cannot be reduced to its parts. But Grelling knew quite well that the concept of Gestalt was also explored by two Berlin psychologists and philosophers who worked in close association with the Berlin Group, Wolfgang Köhler and Kurt Lewin. Among other things, together with Max Wertheimer and Kurt Koffka, the two developed the most influential school of Gestalt psychology of the time. More than this, Köhler was the supervisor of the PhD Dissertation of two core members of the Berlin Group: Walter Dubislav and Carl Hempel. Besides, as we are going to see below (in XY.3.2), between 1920 and 1925 Kurt Lewin worked very closely together with Reichenbach and exercised considerable influence on him.

In their paper (1937/38/1988) Grelling and Oppenheim first try to clarify the concept of Gestalt. To this purpose, they adopt the concept of classifier, coined by Carl Hempel, which determines the classifications of Gestalt arguments, for example, the "pitch" of a musical piece. In a first attempt to define the concept of Gestalt, Grelling and Oppenheim state that "in general, Gestalt can be represented as a classifier whose arguments are complexes and whose values are Gestalt-individuals. ${ }^{9}$ The names of sensory qualities, such as colour, smell, taste etc. can be seen as classifiers" (1937/38/1988, 196 f.). Secondly, Gestalts like musical pieces are complexes which have specific articulation. When a melody is played with "the same tempo and dynamics, but on different sorts of instrument and in a different key", we say that these complexes correspond to one another. In musical theory, the passage from one key to another is called transposition. Grelling's and Oppenheim's final definition of Gestalt is the "invariant of transpositions". According to it, a melody is the Gestalt of a tone sequence.

Significantly, the concept of Gestalt is richer in content than the concept of totality. The totality "is completely determined by its parts and is of the same type as these. In this it differs from complexes. [...] As a result, meaningful statements can be made about tone sequences which cannot be made about totalities"10 (Grelling and Oppenheim 1937/38/1988, 198 f.). In short, Grelling and Oppenheim’s “ontological ranking” is: aggregates, complexes,

\footnotetext{
9 “Gestalt-individual” designates, among other things, every particular artefact, like Mozart's A Little Night Music, or Schubert's Ave Maria.

${ }^{10}$ It deserves notice that Wittgenstein famous criticism of Russell's Theory of Knowledge project in June 1913, based on ideas of Frege, was made from a related perspective of criticism of the complexes in defense of totalities, see Milkov (2013b). Grelling knew that the radical discrimination between complexes and totalities was also drawn by the Polish logicians Tarski and Leśniewski.
} 
totalities, Gestalts. Still different is what Grelling calls "determinational system" in which "there is a division of the whole such that every part of this division stands in the relation $R$ to every other, and every object of which stands in the relation $R$ to at least one part is itself a part of the whole" 11 (1937/38/1988, 199). Importantly enough, this concept was advanced by the Berlin Gestalt-psychologists Köhler and Koffka, and was not used by Ehrenfels. But it was already used by Grelling's old master in philosophy - by Fries $(1822,597)$.

Grelling and Oppenheim underline that the concept of Gestalt is successfully used not only in psychology and in musicology but also in science, including in physics. "In physics our concept of Gestalt could probably be applied to any field, in structural chemistry to a molecule" (1937/38/1988, 197). For example, cases of determinational systems are "selfregulating wholes" like charged and isolated conductors, atoms, atomic nuclei, molecules, cells, organisms, economies - apparently, both objects of living and inorganic matter as well as artefacts. ${ }^{12}$ Grelling also calls the sciences which explored them "reality sciences" (Realwissenschaften) (we shall return to them in XY.5). Only the objects of "formal sciences", logic and mathematics, cannot be ordered in determinational systems.

This brings us back to the lead claim of the present chapter. In the last years of his life, Grelling advanced a project in ontology that can be successfully used in philosophy of nature (Naturphilosophie). Importantly enough, this project was based on elements that Reichenbach developed already in the 1920s, to which, as we are going to see in the next section, he also returned in the last days of his life. In other words, Grelling's intensive work on formal ontology after 1936 reveals essential features of the authentic project of the Berlin Group. In what follows, we are going to substantiate this view.

\section{XY.3. Hans Reichenbach}

\section{XY.3.1. Reichenbach's Program for Comparative Analysis of Science}

Reichenbach's former students remember him as possessing "a unique talent for going to the heart of any issue, clearing away peripheral matters and also cutting through the irrelevancies, which made his teaching a model of clarity. It also endowed his creative philosophical work with genuine profundity" (Salmon 1977, 8). This characteristic of Reichenbach's approach, however, posed its problems. Pursuing "the heart of any issue", often made him overlook some detail, making him an, in this way, one-dimensional philosopher of nature. More often than not he followed one line of exploration, shutting his

\footnotetext{
${ }^{11}$ In another place we called this type or relation reciproca tantum, see Milkov $(2020,98,106,234)$.
} 
eyes to all others. Among other things, this explains why he didn't recognize influences of Richard von Mises on himself, and repeatedly failed to mention books that were close to his conception (cf. Robb 1914, 1924 and Lewis 1929). "Strikingly absent is [also] any reference to Birkhoff and von Neumann's 1936 paper on the logical structure of quantum mechanics" (Glymour and Eberhardt 2016).

In XY.2.3 we have already spoken about the principle of relative a priori in science, introduced by Fries and later rediscovered by Reichenbach. One of its implications is that philosophers have to 'logically analyze' every new important theory of science. Secondly, we cannot strictly discriminate one science from another, so that the principles that are valid for one science are void for others. This means that the new philosophers of nature (Naturphilosophen) have to examine the principles of all sciences. Ostensibly, Reichenbach hoped that the 'logical analysis' of different sciences could bring to light connections between their ever-changing principles (Milkov 2011, 151). He presented this idea in several papers published around 1930: "New Approaches in Science" (1929/1978), "The Philosophical Significance of Modern Physics" (1930/1978), and “Aims and Methods of Modern Philosophy of Nature" (1931/1978) (the latter is sometimes considered the manifesto of the Berlin Group).

Among other things, this task led Reichenbach to transform the Berlin-based 'Society for Empirical Philosophy', which Reichenbach took over from Joseph Petzoldt in June 1929, into the 'Berlin Society of Scientific Philosophy'. First, by the end of 1931, the name change was carried out, allegedly following a suggestion by David Hilbert. But not just the title of the Society was changed. After February 1932, and until Reichenbach left Berlin in July 1933 , the term "empiricism" appeared no longer in any of the titles of the 32 presentations delivered. This tendency persisted in the ten lectures presented after Reichenbach departure, when the Society was led by Dubislav. Of course, it was not the case that Reichenbach abandoned the method of empiricism in his philosophy of nature - it was his unwavering position. Rather, to Reichenbach the joint philosophical effort of the best informed, innovative scientists of the time that had presentations at his Society was of prime importance. ${ }^{13}$ Apparently, the tentative task was no less than to discover the relative a priori not only of one science alone but of science in general. This conception perfectly harmonized with the pronounced interdisciplinary profile of the presentations at the Society.

\footnotetext{
${ }^{12}$ Moritz Schlick (1935/1979), in contrast, refused to accept wholes in his philosophy of science.
} 


\section{XY.3.2. Kurt Lewin's Conception of Genidentity}

It is little known today, and even less discussed, that between 1917 and 1925 Reichenbach collaborated with the psychologist, gestalt theorist and former student of Carl Stumpf, Kurt Lewin. ${ }^{14}$ In fact, this was the first variant of the Berlin Group. Reichenbach and Lewin knew each other from 1911 when both had studied in Munich. In 1917, during the Great War, the two worked together for the Prussian Ministry of War and even published a joint "Draft for an Aptitude Test for Radio-Telegraphists" (co-authored by Otto Lipmann) (HR 024-16-02).

Lewin explicitly advanced a theory of science that was to replace the conventional theory of knowledge. The deficiency of the Neo-Kantians is, so Lewin, that their analyses "were still not sufficiently concrete. [...] The[ir] examples often carry the character of mere illustrations" (Lewin 1925/1981, 61). Significantly, as we already have seen (in XY.2.3), the same reproach against Kant was made, but from different perspective, by Jacob Fries; and against Hermann Cohen and Ernst Cassirer by Nelson (1905) and Grelling (1907).

As Reichenbach wrote in his review (1921) of Lewin's (1920) paper, in Lewin's philosophy of science the fundamental, "scientific-theoretical equivalent" concepts of different sciences are compared, or analyzed. A product of this analysis is the concept of genidentity. Lewin introduced it as constitutive both in biology, in physics and also in chemistry. The point is that the objects and events of both biological and physical world develop in time but at the same time retain their identity. Levin called this type of identity "genidentity". For example, the relation between the egg and the hen is that of "biological genidentity": it represents different stages of development of the same biological individual. An important point is that genidentity is not a logical identity but relation of the existence of constructs. The problem here is ontological, and Grelling immediately understood this (see Grelling 1925).

But while Lewin insisted that different sciences have structural similarities, he also maintained that we cannot speak of identity between their terms. These refer to different angles, or modalities of reality. That is why the differences between these structures are considerable. This also concerns the concept of genidentity. In particular, Lewin speaks about "individual genidentity", or about "simple genidentity" in biology, and about "complete genidentity" in physics. Whereas with complete genidentity we have a monotonic sequence of the slices of objects and events one after another, with simple genidentity this is not the case. Reichenbach (1924), who, as we are going to see in the next section, adopted Lewin's

\footnotetext{
${ }^{13}$ On the qualification of the presenters at the Berlin Society of Scientific Philosophy see Milkov $(2013,10)$.
} 
concept, maintained that whereas the series in physic are continuous, those in biology are discrete. $^{15}$

\section{XY.3.3. Reichenbach on Genidentity}

Reichenbach grasped the importance of Lewin's conception immediately after he read Lewin's paper (1920) in manuscript. He promptly adopted it in his first book, The Theory of Relativity and A Priori Knowledge (1920/1965). In it, the concept of genidentity is presented as an a priori constitutive principle of human knowledge which indicates "how physical concepts are to be connected in sequences in order to define 'the same thing remaining identical with itself in time"” $(1920 / 1965,53)$. In fact, this concept refers to a characteristic of physical objects and events that is more fundamental than the simple temporal order. But it is a principle since it is not a necessary condition: we simply assume that it is correct. ${ }^{16}$

Shortly afterwards, however, in The Axiomatization of the Theory of Relativity (1924/1969), Reichenbach dropped the concept of genidentity. Arguably, this was an implication of the replacement of the coordinative principles by coordinative definitions and of the conventionalism, which Reichenbach adopted under Schlick's influence. Now Reichenbach eliminated the measuring rods and clocks he postulated in his philosophy of nature in $(1920 / 1965,20)$ and derived the topological properties of space and time from lightsignals. ${ }^{17}$ To be more explicit, genidentity was substituted by the "mark principle" which maintains that when an event "is marked at $P$, the mark can also be observed at $P$ "” $(1924 / 1969,27)$.

Immediately after finishing the Axiomatization, Reichenbach sent a copy of the book to his collaborator at the time - Kurt Lewin. Lewin, however, criticized some of its theses and, importantly enough, Reichenbach agreed with him. As a result, under Lewin's influence, Reichenbach introduced in his philosophy of nature the fork asymmetry account of time, which came to replace the simple causal chains. The causal chains are to be open.

\footnotetext{
${ }^{14}$ In 1911/12 Reichenbach himself studied psychology with Carl Stumpf in Berlin.

${ }^{15}$ To be precise, in (1921) Reichenbach underestimated the difference between these two types of identity but soon (in 1924) corrected his view with Lewin's support; see Padovani (2013, 111-112, n. 42)

${ }^{16}$ Grelling hold the problem of genidentity at the center of his attention all the time. In his (1936) paper, for example, he connected genidentity with Leibnitz's principle of identity of indiscernibles. Grelling defended the latter against the formalist critic of Wittgenstein and Friedrich Waismann. In fact, Grelling (1936) paper can be seen as a prelude to his ontological papers of 1937-39 we discussed in $§ 2.4$.

${ }^{17}$ See Reichenbach's letter to Schlick of January 22, 1922. (Schlick collection) The only author of the time who noted this change in Reichenbach's view was Grelling who mentioned it in his review of Lewin (1922) (1925, columns 688-689). Significantly, Grelling underlined in it the strong relation of Lewin's book to Reichenbach's studies.
} 
Significantly, this “account relies quite consistently on Lewin's analysis of the splitting and intersecting series" (Padovani 2013, 119).

These changes in Reichenbach's understanding, made under influence of a "reality scientist" (see on this concept § 2.4) - Kurt Lewin, are clearly discernible in "The Causal Structure of the World" (1925/1978a), where he used the notion of direction of time (of timeasymmetry) for the first time in his writings. In parallel, Reichenbach returned to philosophical realism, embracing

\begin{abstract}
a metaphysical axiom, a belief in the uniformity of the world that cannot be proven and that nonetheless makes a positive assertion about the world. We formulate, in this principle, the most universal feature of the real. It cannot be established upon the basis of the knowing mind; rather, it asserts something about things-in-themselves. (Reichenbach 1925/1978b, 292)
\end{abstract}

As it can be expected, this position brought on severe criticism from Schlick.

After The Philosophy of Space and Time was published, Reichenbach was silent on genidentity for years. He returned to this concept, on a large scale, only in what is often considered his "philosophical testament", The Direction of Time (1956). ${ }^{18}$ However, whereas in The Philosophy of Space and Time Reichenbach was interested in applying the concept of genidentity to the theory of relativity, in The Direction of Time he applied it to the quantum mechanics.

In more concrete terms, in The Direction of Time Reichenbach changed his position from 1925, and this in the following way. According to the laws of classical mechanics, the time can be both reversible and irreversible. Time is only irreversible in quasi-closed (isolated) physical systems which have finite lifetime. This was his position from 1928. Now, however, Reichenbach held that it is possible that time have different sections, in some of which "it have directions which would be statistically expressed in the same way as for temporary open universe." (p. 134) In support of this position, Reichenbach referred to a paper of the young Richard Feynman (1949) who pleaded for particles moving back in time.

This last point brings us to an important characteristic of Reichenbach as a philosopher of nature. This "evangelist of science" (van Fraassen) managed to discuss, with

\footnotetext{
${ }^{18}$ Be this as it may, between 1928 and 1953 Reichenbach continued to be engaged with ontological analyses. In Experience and Prediction, for example, he insisted, in an important discussion with the logical positivists, that "the transition from external things to impressions [perception] cannot be interpreted as reduction; it is of another type of logical structure." $(1938,105)$ As an illustration, as if starting from Grellings and Oppenheim (1937/38) arguments for Gestalt complexes we discussed in $\S 2.4$, Reichenbach suggested the example with the melody: it is not reducible to its elements.
} 
philosophical methods, problems of the cutting age science of his time. To start with, he was one of the first philosophers to immediately realize the paradigm changing significance of Einstein's theory of relativity. Secondly, as Reichenbach himself maintained, the principle of indeterminacy in quantum mechanics "was initially suggested by [his] philosophical considerations concerning the principle of causality."19 $(1931,377)$ His task as philosopher was simply "to point out this possibility". (Ibid.) Thirdly, as we just saw, Reichenbach immediately realized the importance of the revolutionary ideas about causality in quantum mechanics of Richard Feynman.

All these facts support Reichenbach's claim that his philosophy works in direct connection with the results achieved by science. However, philosophy is not identical with science. It has its own methods like that of logical and ontological analysis which help to better appreciate the results of science, and even to predict them.

\section{XY.4. Carl Hempel, the Logic of Explanation and the General Philosophy of Science}

Another scientist who worked together with Reichenbach in the early 1920s was the chemist and private scholar Paul Oppenheim (1885-1977). Reichenbach met him around 1921 in Stuttgart and actively encouraged him to develop his ideas in print. In his first book (1926), Oppenheim warmly thanked Reichenbach for his support. Above all, Oppenheim explored the order of sciences. In particular, he was adamant about demonstrating that there is no break between natural science and the humanities. Between 1934 and 1936 Oppenheim worked together with Hempel and between 1936 and 1938 with Grelling. After the Second World War he collaborated with a series of young, talented philosophers like Hilary Putnam and Nicholas Rescher.

In order to better understand the kind of collaboration Oppenheim was engaged with, it can be helpful to turn attention to the information about it provided by Nicholas Rescher, who worked with him on a joint paper (Rescher and Oppenheim 1955):

\footnotetext{
What Oppenheim principally contributed to our collaboration were two things: (1) the topic of the investigation, and (2) a guiding concern for structural issues. [...] But beyond this guiding concern for a theory of ordering concepts, Oppenheim made very little substantive contribution to the investigation. He was like an Aristotelian first mover, having set a project in motion (in a rather generally indicated) direction, he stood back and let nature take its course, with minimal interference as long as things kept on track. (Rescher 1997, 159)
}

\footnotetext{
${ }^{19}$ It is to mention that other scientists and scientific theorists denied this claim.
} 
By the considerable freedom Oppenheim's collaborators enjoyed in their work, it deserves notice that although Oppenheim's joint work with Hempel and Grelling took place in, practically, the same period of time, it brought about markedly different results. In short, while Hempel pushed a project close to logic, Grelling advanced the already discussed (in $\S$ 2.4) explorations in ontology. This brings us to a discrete split in the Berlin Group in two wings - philosophers of nature (Naturphilosophen) (Reichenbach and Grelling) and philosophers of science (Dubislav and Hempel).

To be more explicit, Hempel's object of investigation in (Hempel and Oppenheim 1936, 1936/2015) was the logical analysis of personal psychology - of the psychological types. He, together with Oppenheim, observed a recent change in the concept construction of all sciences but in particular of contemporary typology which moves from concepts of classification to concepts of topological order and further, to metrical concept construction in physics $(1936 / 2015,373)$. Hempel also maintained that sciences make use of different kinds of concept formation simply because they are at different stages of development. He, however, underlined that the concept formation of diverse sciences is not of logically different types. Hempel further held that the conventional explorations of concept formation with the help of "traditional logic", but also with the "theory of propositional function", cannot help. In any case, it is inappropriate to treat concepts with the help of classes, propositional functions, or other "rigid conceptual schemes" (Hempel and Oppenheim 1936/2015, 366). Hempel's project was to replace them with "elastic" notions (a term Hempel adopts from Bergson). By way of an endnote, it is important to notice that exactly Hempel's pursuit of logically analyzing the concepts of science later led him in the mid1940s, motivated by Oppenheim, to explore the logic of confirmation and explanation (Rescher 1997, 161 f.).

As a matter of historical fact, Hempel's slant to logic was developed under the influence of Walter Dubislav, with whom Hempel worked while in Berlin. Among other things, this connection is confirmed by the fact that Hempel read the proofs of Dubislav's Die Philosophie der Mathematik in der Gegenwart (1932, v). Another point supporting this claim is that Hempel $(1933,1934)$ wrote two reviews of Dubislav's Philosophy of Nature (1933), assessing this work as "extremely stimulating, concise and clearly written" (Hempel 1933, 56). He was explicit that what distinguished Dubislav's volume from studies in the philosophy of nature by the likes of the Viennese logical positivists was that it didn't 
primarily concern itself with specific problems of science. Instead, it systematically explores the logical and methodological problems of scientific knowledge (Hempel 1934, 760). As it turned out, this was a program that Hempel himself would follow in his Philosophy of Natural Science (Hempel 1966), regarded today as a standard work in the general philosophy of science.

\section{XY.5. Epilogue}

Some 50 years after the paper of Grelling and Oppenheim was published in Erkenntnis (1938/39a), Peter Simons translated it, together with two other papers, into English and commented on them (in Smith 1988, 191-225). In Simons' judgment, the paper of Grelling and Oppenheim "cut ontological ice” (Simons 1988, 161).

As a matter of fact, Simons was part of a new wave of formal ontologists (Barry Smith, Kevin Mulligan, and Dale Jacquette, among them), inspired by the metaphysical turn in philosophy in the 1970s and 1980s epitomized by David Lewis. The new ontologists outlined a new direction of development of philosophy. In particular, they developed an alternative conception of logic. The problem is that the standard first order logic is not thus helpful by treating objects of the real world, such like universals, types, and processes. To be sure, it's "universe of discourse consists of particular items" only (Smith 2008, 110). One can successfully use the conventional logic mainly in mathematics, the objects of which are not situated in space and time. For the objects of the real world we will need an alternative logic, for example, logic of terms, but also formal ontology.

It is true that the new wave of ontologists didn't produce works in the realm of philosophy of nature or philosophy of science and had practically no influence on them. Be this as it may, their arguments indicate the direction in which Reichenbach's wing of the Berlin Group developed many years ago - the realist ontology of nature. It is a matter of fact that the members of the Berlin Group in general worked together with representatives of what Grelling has called "reality sciences" (Realwissenschaften) (see XY.2.4), the object of which are situated in space and time. This claim is also supported by the fact that, as we have seen in XY.3.2, between 1920 and 1925 Reichenbach collaborated with the psychologist and gestalt theorist Kurt Lewin (in fact, much closer than with Moritz Schlick). Grelling, on his side, collaborated for years with the medical doctor Heinrich Poll (see Poll 1933). Finally, the Berlin Society for Scientific Philosophy, as different from the Berlin Group, was led for years by the medical professor Friedrich Kraus. 
We see the specific approach of the ontological wing of the Berlin Group as a promising venue that can help to improve the relation between philosophy and science also today. It is an alternative both to the philosophy of nature developed in the wake of the logical positivist and to Hempel's general philosophy of science exploring, among other things, explanations in science. In this sense, our hope for a new start of the philosophy of nature is connected with a turn zurück zu Reichenbach. There could be no better guide in such a twist than Kurt Grelling.

\section{XY.6. References}

Andersen, Ross. 2012. "Has Physics Made Philosophy and Religion Obsolete?" The Atlantic, April 23.

Apelt, Ernst Friedrich. 1854. Theorie der Induktion. Leipzig: Engelmann.

Birkhoff, Garrett, and Johannes von Neumann. 1936. "The Logic of Quantum Mechanics", Annals of Mathematics 37 (4): 823-843.

Corry, Leo. 2004. David Hilbert and the Axiomatization of Physics (1898-1918), Dordrecht: Kluwer.

Dubislav, Walter. 1932. Die Philosophie der Mathematik in der Gegenwart. Berlin: Junker und Dünnhaupt.

—. 1933. Naturphilosophie. Berlin: Junker und Dünnhaupt.

Ehrenfels, Christian von. 1890. "Über Gestaltqualitäten”, Vierteljahrschrift für

wissenschaftlichen Philosophie 14: 249-292.

Feynman, Richard. 1949. "The Theory of Positrons", Physical Review 76: 749-759.

Friedman, Michael. 2001. Dynamics of Reason. Stanford: CSLI Publication.

—. 2005. "Ernst Cassirer and the Contemporary Philosophy of Science", Angelaki 10: 119128.

Fries, Jacob Friedrich. 1822. Mathematische Naturphilosophie. Heidelberg: Winter.

—. 1842. Versuch einer Kritik der Prinzipien der Wahrscheinlichkeitsrechnung. Leipzig: Braunschweig.

Glymour, Clarl, and Frederick Eberhardt. 2016. "Hans Reichenbach", The Stanford Encyclopedia of Philosophy, Edward N. Zalta (ed.), URL = $<$ https://plato.stanford.edu/entries/reichenbach/> 
Grelling, Kurt. 1907. "Das gute, klare Recht der Freunde der anthropologischen

Vernunftkritik verteidigt gegen Ernst Cassirer." Abhandlungen der Fries 'schen Schule 2 (2): $155-190$.

—. 1910a. Die Axiome der Arithmetik mit besonderer Berücksichtigung der Beziehungen zur Mengenlehre. Göttingen: Dieterichsche Universitäts-Buchdruckerei (Ph.D. Thesis).

—. 1910b. "Die philosophischen Grundlagen der Wahrscheinlichkeitsrechnung." Abhandlungen der Fries 'schen Schule, n.s., 3 (3): 440-478.

—. 1916a. "Philosophische Grundlagen der Politik." Sozialistischen Monatshefte 22 (3): 1045-1065.

—. 1916b. Anti-j'accuse. Eine deutsche Antwort. Zürich: Orell.

—. 1925. "Kurt Lewin, Der Begriff der Genese in Physik, Biologie und

Entwicklungsgeschichte." Deutsche Literaturzeitung 14: 685-690.

—. 1932/33. "Bemerkungen zu Dubislavs 'Die Definition.” Erkenntnis 3: 189-200.

—. 1939/1988. “A Logical Theory of Dependence.” In Foundations of Gestalt Theory, edited by Barry Smith, pp. 217-226. Munich/Vienna: Philosophia Verlag.

—. 1969. "On Definitions by Equivalence Classes and by Group Invariants.” Methodology and Science 2: 116-122.

—. 1970. "On the Logical Relations between Groups and Equivalence Relations." Methodology and Science 3: 5-17.

Grelling, Kurt, and Paul Oppenheim. 1937/38/1988. "The Concept of Gestalt in the Light of Modern Logic.” In Foundations of Gestalt Theory, edited by Barry Smith, pp. 191-205. Munich/Vienna: Philosophia Verlag.

_ 1939/1988. "Logical Analysis of 'Gestalt' as 'Functional Whole"”. In Foundations of Gestalt Theory, edited by Barry Smith, pp. 210-216. Munich/Vienna: Philosophia Verlag.

Hempel, Carl. 1933. "Walter Dubislav, Naturphilosophie.” Jahrbuch über die Fortschritte der Mathematik 59 (1): 56-57.

—. 1934. "Walter Dubislav, Naturphilosophie." Deutsche Literaturzeitung 55: 759-762.

—. 1966. Philosophy of Natural Science. Englewood Cliffs (NJ): Prentice-Hall.

Hempel, Carl, and Paul Oppenheim. 1936. Der Typusbegriff im Lichte der neuen Logik: wissenschaftstheoretische Untersuchungen zur Konstitutionsforschung und Psychologie. Leiden: Sijthoff. 
—. 1936/2015. "Die logische Bedeutung des Typusbegriffs." In Die Berliner Gruppe, edited by Nikolay Milkov, pp. 365-375. Hamburg: Felix Meiner.

—. 1948. "Studies in the Logic of Explanation". Philosophy of Science 15(2): 135-175.

Howard, Don. 2003. "Two left turns make a right: On the curious political career of North American philosophy of science at midcentury." In Logical Empiricism in North America, eds. Gary Hardcastle and Alan W. Richardson, pp. 25-93. Minnesota: University of Minnesota Press.

Lewin, Kurt. 1920. "Die Verwandtschaftsbegriffe in Biologie und Physik und die Darstellung vollständiger Stammbäume." Abhandlungen zur theoretischen Biologie 5: 38-73.

—. 1922. Der Begriff der Genese in Physik, Biologie und Entwicklungsgeschichte. Berlin: Springer.

Lewis, C.I. 1929. Mind and the World Order: Outline of a Theory of Knowledge. New York: Charles Scribners.

Meyerson, Émile. 1930. Identität und Wirklichkeit. Trans. by Kurt Grelling. Leipzig: Akademische Verlagsgesellschaft.

Milkov, Nikolay. 2011. (ed.) Hans Reichenbach: Ziele und Wege der heutigen Naturphilosophie. Hamburg: Meiner.

—. 2013a. "The Berlin Group and the Vienna Circle: Affinities and Divergences." In The Berlin Group and the Philosophy of Logical Empiricism, eds. Nikolay Milkov and Volker Peckhaus, pp. 3-32. Dordrecht: Springer.

—. 2013b. "The Joint Philosophical Program of Russell and Wittgenstein and Its Demise", Nordic Wittgenstein Review 2: 81-105.

—. 2015. “Einleitung: Die Berliner Gruppe des logischen Empirismus”, Die Berliner Gruppe: Texte zum Logischen Empirismus. Eine Anthologie, Hg. Nikolay Milkov, Hamburg: Felix Meiner Verlag, pp. ix-lxi.

—. 2020. Early Analytic Philosophy and the German Philosophical Tradition. London: Bloomsbury Academic.

Nelson, Leonard. 1905. "Logik der reinen Erkenntnis, von Hermann Cohen.” Göttingische gelehrte Anzeigen 167: 610-630.

Oppenheim, Paul. 1926. Die natürliche Anordnung der Wissenschaft. Jena: Gustav Fischer. Peckhaus, Volker. 1994. "Von Nelson zu Reichenbach: Kurt Grelling in Göttingen und Berlin.” In Hans Reichenbach und die Berliner Gruppe, eds. L. Danneberg et al., pp. 5386. Braunschweig: Vieweg. 
—. 2013. "The Third Man: Kurt Grelling and the Berlin Group." In The Berlin Group and the Philosophy of Logical Empiricism, eds. Nikolay Milkov and Volker Peckhaus, pp. 231-243. Dordrecht: Springer.

Pulte, Helmut. 2013. 'J.F. Fries' Philosophy of Science, the New Friesian School and the Berlin Group: on Divergent Scientific Philosophies, Difficult Relations and Missed Opportunities." In The Berlin Group and the Philosophy of Logical Empiricism, eds. Nikolay Milkov and Volker Peckhaus, pp. 43-66. Dordrecht: Springer.

Padovani, Flavia. 2013. "Genidentity and Topology of Time: Kurt Lewin and Hans Reichenbach." In The Berlin Group and the Philosophy of Logical Empiricism, eds. Nikolay Milkov and Volker Peckhaus, pp. 97-122. Dordrecht: Springer.

Poll, Heinrich. 1933. “Genetik und Melistik als Grundlage des ärztlichen Denkens”. In Einheitsbestrebungen in der Medizin, Dresden und Leipzig, 219-28.

Reichenbach, Hans. 1920/1965. The Theory of Relativity and A priori Knowledge. Berkeley and Los Angeles: University of California Press.

—. 1921. "Kurt Lewin, Die Verwandtschaftsbegriffe in Biologie und Physik und die Darstellung vollständiger Stammbäume.” Die Naturwissenschaften 9: 51.

—. 1924/1969. The Axiomatization of the Theory of Relativity, Berkeley and Los Angeles: University of California Press.

—. 1924. "Kurt Lewin, Der Begriff der Genese in Physik, Biologie und Entwicklungsgeschichte." Psychologische Forschung 5: 188-190.

—. 1925/1978a. "The Causal Structure of the World and the Difference between Past and Future.” In Hans Reichenbach: Selected Writings 1909-1953, Volume Two, eds. Maria Reichenbach and Robert S. Cohen, pp. 81-119. Dordrecht: D. Reidel.

—. 1925/1978b. "Metaphysics and Natural Science.” In Hans Reichenbach: Selected Writings 1909-1953, Volume One, eds. Maria Reichenbach and Robert S. Cohen, pp. 283-297. Dordrecht: D. Reidel.

—. 1928. Philosophie der Raum-Zeit-Lehre. Berlin: de Gruyter.

—. 1929/1978. "New Approaches in Science.” In Hans Reichenbach: Selected Writings 1909-1953, Volume One, eds. Maria Reichenbach and Robert S. Cohen, pp. 245-257. Dordrecht: D. Reidel.

—. 1930/1978. "The Philosophical Significance of Modern Physics.” In Hans Reichenbach: Selected Writings 1909-1953, Volume One, eds. Maria Reichenbach and Robert S. Cohen, pp. 304-323. Dordrecht: D. Reidel. 
—. 1931/1978. "Aims and Methods of Modern Philosophy of Nature." In Hans

Reichenbach: Selected Writings 1909-1953, Volume One, eds. Maria Reichenbach and

Robert S. Cohen, pp. 359-388. Dordrecht: D. Reidel.

—. 1938. Experience and Prediction, Chicago: University of Chicago Press.

—. 1944. "Bertrand Russell's Logic.” In The Philosophy of Bertrand Russell, edited by Paul Schilpp, pp. 23-54. Evanston (Ill.): Northwestern University Press.

—. 1956. The Direction of Time. Berkeley (Cal.): University of California Press.

Rescher, Nicholas. 1997. "H2O: Hempel-Helmer-Oppenheim, an episode in the history of scientific philosophy in the 20th century." Philosophy of Science 64 (2): 334-360.

Rescher, Nicholas, and Paul Oppenheim. 1955. "Logical Analysis of Gestalt Concepts."

British Journal for the Philosophy of Science 6: 89-106.

Robb, A. A. 1914. A Theory of Time and Space. Cambridge: Cambridge University Press.

—. 1924. The Absolute Relations of Time and Space. Cambridge: Cambridge University Press.

Salmon, Wesley. 1977. “The Philosophy of Hans Reichenbach.” In Hans Reichenbach:

Logical Empiricist, edited by W. C. Salmon, pp. 1-84. Dordrecht: Reidel.

Schlick, Moritz. 1935/1979. “On the Concept of Wholeness.” In Moritz Schlick:

Philosophical Papers, Volume II, 1925-1936, eds. H. Mulder and B.F.B. van de Velde-

Schlick, pp. 388-399. Dordrecht: D. Reidel.

Simons, Peter M. 1988. "Gestalt and Functional Dependence.” In Foundations of Gestalt

Theory, edited by Barry Smith, pp. 158-190. Munich/Vienna: Philosophia Verlag.

Smith, Barry. 2008. "The Benefits of Realism: A Realist Logic with Applications." In Applied Ontology, eds. K. Munn and B. Smith, pp. 109-124. Frankfurt: Ontos.

Weinberg, Steven. 1992. Dreams of a Final Theory. New York: Vintage Books. 